\title{
Proximity and Voting for Professional Sporting Stadiums: The Pattern of Support for the Seahawk Stadium Referendum
}

\author{
Brady P. Horn, Michael Cantor, and Rodney Fort
}

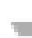

March 24, 2015

Horn: Department of Economics, University of New Mexico; Cantor: Sterling Project Development, New York; Fort: Sport Management, University of Michigan.

Corresponding Author:

Rodney Fort

Sport Management

University of Michigan

1402 Washington Heights, Rm. 3150

Ann Arbor, MI 48109-2808

735-647-8989

rodfort@umich.edu

\section{Abstract:}

This paper evaluates voting behavior on the Seahawk Stadium referendum in the State of Washington. For our empirical strategy we implement both the linear probability model and a group logit model, which gives greater weight to voting areas with greater number of votes cast. We find that voting support was lowest among those living closest to the proposed stadium site, while voting support was highest among those within "easy access" of the stadium. This nonlinear distance effect differs from the typical "proximity" effect found in most professional sporting stadiums in the U.S.; however, it is consistent with a referendum-voting outcome for a professional soccer stadium in Germany and public projects such as national forests.

JEL Classification Codes: R53, H71, L83. Keywords: Referenda, Sports facilities.

The authors would like to thank Jill McCluskey, Jonathon Yoder, Alok Bohara, and Robert Berrens for their valuable comments.

This is the author manuscript accepted for publication and has undergone full peer review but has not been through the copyediting, typesetting, pagination and proofreading process, which may lead to differences between this version and the Version of Record. Please cite this article as doi: 10.1111/coep.12108

This article is protected by copyright. All rights reserved. 


\section{Proximity and Voting for Professional Sporting Stadiums: The Pattern of Support for The Seahawk Stadium Referendum}

Dear fellow Washingtonians:

I've said from the start I wouldn't go forward with purchasing the Seahawks and building a new stadium and exhibition center without your approval. Knowing a "Yes" vote will be an act of trust, I'd like to share my commitments to this public/private partnership... Should we move forward, the new stadium and exhibition center will be a valuable asset - bringing our communities together and benefiting the state for decades to come.

$$
=
$$

_Paul Allen (Secretary of the State of Washington, 1997, p. 4).

\section{Introduction}

Referendum voting outcomes have proven informative about economic behavior in many areas of government spending. Primarily, analysis has been in education, health care, and nuclear power. Here, we examine another large-scale public endeavor.

Through estimation of a precinct-level model of yes votes, we examine the results of a referendum vote in the State of Washington to subsidize the building of what is now known as CenturyLink Field (previously Qwest Field) in Seattle, Washington, USA. We confine this analysis to just the county where nearly all of the action occurred, the county that would eventually hold the new facility. Direct examination of the voting results shows that the highest level of support occurred in and around King County.

Looking at this one county in detail informs us in ways that looking at the same model across counties cannot. For example, it is difficult to escape the conclusion that voters in close proximity to the site were much more likely to vote against the referendum, while 
those in precincts within short driving distance (typically wealthier and more populous precincts) were much more likely to vote in favor. ${ }^{1}$

Results of an empirical precinct-level voting model are entirely consistent with the inspection results—-proximity and population really do rule. However, while in general support for a stadium tends to increase with proximity to a stadium (Coates and Humphreys, 2006; Dehring, Depken II, and Ward, 2008) from an individual voter's perspective, publicly subsidized stadiums have both positive and negative aspects. As a result, the costs of being in close proximity to a stadium can overcome benefits, and that is what we find. Consistent with the Ahlfeldt and Maennig (2012), who find that voters nearest to the proposed soccer stadium in Munich were more likely to vote against the referendum, we find that voting support for CenturyLink Field is actually smallest in close proximity to the proposed facility. However, a novel result is that voting support for the referendum was highest at 10 to 30 miles driving distance from the stadium and beyond that distance, as time costs increase, voting support falls off.

Further, consistent with previous works at the city-level and county-level, the odds of a yes vote were higher in higher-income precincts and in precincts with higher proportions of minority voters. Surprisingly, we find little effect of the proportion of renters relative to homeowners, which could be related to the "homevoter" hypothesis

${ }^{1}$ Of course, every choice has a cost and ours is that we are unable to design measurements to capture the well-known agenda control problem in referendum voting at the single-county level (originally, Romer and Rosenthal, 1978; see Filimon, Romer and Rosenthal, 1982; and Fort, 1988, 1997). Chang and Turnbull (2002) summarize the numerous works where agenda control has mattered in empirical analyses of voting. For example, the "reversion threat" does not vary for just a single county. All we can say is that the vote was very close, 51.1 to 49.9, suggesting evidence of agenda control (Fort, 1988). 
(Fischel, 2005; Dehring, Depken, \& Ward, 2008). Finally, the odds of a yes vote increased in older demographic precincts but decreased in precincts with higher proportions of white-collar workers.

The paper proceeds as follows. In Section II, we give the background on the election. The history of the precinct-level model of the odds of a yes vote along with a data description is in Section III. The results are in Section IV and conclusions round out the paper in Section V.

\section{Background}

Referendum 48 was decided in a statewide special election on June 17, 1997. The specific details of the stadium finance agreement can be found in the 28-page Official Washington Voter's Pamphlet (Secretary of the State of Washington, 1997). Overall, the ballot stated that the stadium would cost approximately $\$ 425$ million with a $76-24$ publicprivate split (\$323 million public money).

Some revenue elements to cover the public portion were added diversions from private spending. A mix of user and tourist taxes, including ticket and parking taxes and a King County (Seattle) room tax extension, were set to cover $\$ 95$ million of the total. The remaining elements in the public portion, although touted otherwise, were direct diversions of funds spent elsewhere across the state on public services. The most obvious of these was sales tax forgiveness amounting to $\$ 101$ million. Less obvious was $\$ 127$ million from new sports-related lottery games. To the extent that new lottery games simply redistribute a given propensity in the population to gamble, this new game would 
divert funds from their previously allocated purpose. In 1997, before the referendum passed, lottery funds were exclusively dedicated to education construction projects for K12 and higher education, economic development, problem gambling prevention and treatment, and the state's General Fund. Thus, there were impacts not just on private spending through new revenue devices, but also on the previous distribution of public $=$ spending.

The final element in the public portion was $\$ 27$ million in tax breaks to the builders of the stadium. Economically, it is difficult to determine the true cost of this $\$ 27$ million "contribution." If the next best opportunity for these builders was a purely private

endeavor, was $\frac{\$ 27 \text { million }}{\$ 425 \text { million }} \cong 6.4$ percent the "going rate" tax break on privately

financed development? If the next best opportunity for these builders was a purely public endeavor, then this $\$ 27$ million appears to be a phantom contribution; the public never would have born this cost in the first place since, presumably, the same tax break would have applied. If the latter was the case, then the true cost of the stadium was actually \$398 million and the public-private split was 74-26 (\$296 million public).

Proponents did all they could to portray Referendum 48 as essential to keeping the Seahawks in Seattle, building on threats and actions by the previous owner, Ken Behring, to move the team to California (this and following details are in Fort, 1999). Los Angeles was without an NFL team and various owner interests in the L.A. area were actively pursuing NFL teams. Behring tried to move the Seahawks to Hollywood Park just prior 
to the referendum episode. The NFL, under a league-enforced cooling off period turned him back.

During the cooling off period, Paul Allen paid $\$ 10$ million for an option to buy the Seahawks and made it clear he would only exercise this option if a new, publicly funded, stadium would be built. If the option expired, the team would still belong to Behring whose past behavior predicted that the team would move. Thus, Allen's option left a unique underlying threat that voters would lose their team if they did not come through with the stadium subsidy by passing Referendum 48 .

The referendum passed by a slight 51.1 percent of the popular vote- $-820,364$ yes; 783,584 no (Secretary of the State of Washington, 2009). Figure 1 shows the geographic distribution of yes votes on Referendum 48 by coding the yes vote percentage by precinct for the most densely populated part of King County (the county actually extends a bit farther south and quite a bit more east but especially the latter has such low population that not much is missed by the focus on the portion of King County in Figure 1). Visual inspection suggest that precincts that strongly favored Referendum 48 are outside of the core of opposition next to the proposed site ("starred" in Figure 1) and that support for the referendum was non-linear by distance (opposition immediately around the site, then support by those within easy access by car, falling off beyond that).

\section{The Model, Variable Identification, and the Data}

Borcherding and Deacon (1972) and Deacon and Shapiro (1975) originally

explored the calculus of the individual referendum voting decision (direct modeling and 
estimation of the direct demand for expenditure on publicly provided goods comes from Bergstrom and Goodman, 1973). As they point out, the main problem is that individual voting is not observed. Lacking individual voting data, it is typical to appeal to a pivotal voter like the "median voter" (Downs, 1957). Under this choice, the individual calculus informs empirical analysis, but one only need analyze one representative individual, namely, the voter holding the median expenditure preference.

However, three other issues arise. What statistics represent the median voter? For example, does the pivotal median preference follow from being at the median in income? In addition, what is the appropriate level of aggregation for the statistical characterization of the pivotal voter (a comprehensive review is in Hoxby, 2000)? Finally, there may be situations where actual spending outcomes are not the median voter's most preferred outcome. This is the well known Romer and Rosenthal (1978) "reversion threat" under agenda control (see the other citations in the introduction as well). ${ }^{2}$

The literature on referendum voting in the sports context is not quite so extensive. Agostini, Quigley, and Smolensky (1997) estimated a voting model at the precinct level for a ballpark in the San Francisco area finding that socio-demographic data explain voting outcomes. Their analysis found that higher income, educated, and high-status job voters were more in favor of the ballpark initiatives than their lower income, educated, and workforce counterparts. No attempt was made to determine whether or not proximity to the proposed stadium locations impacted voter decisions. Fort (1997) studied stadium-

${ }^{2}$ However, as we stated earlier, capturing this empirically for just a county in a state wide election was not possible. All we can observe is that the closeness of the election is suggestive of agenda control. 
funding referenda for their general outcome characteristics and the importance of agenda control, but does no formal estimation of voting outcomes. Brown and Paul (1999) argue in support of the classic concentrated benefits/dispersed costs outcome common in the public choice approach for a city referendum in Cincinnati. Fort (1999) categorizes referenda in terms of their impact on spending levels compared to spending levels determined by elected representatives instead. Depken (2000) estimates fan loyalty and shows that it helps determine voting outcomes on nine city stadium elections.

More recently the issue of stadium proximity has become an area of increased interest in the literature. For instance, a number of studies have shown that the construction of a stadium has a positive impact on property values (Tu, 2005; Dehring, Depken II, and Ward, 2007; Feng and Humphreys, 2012; Ahlfeldt and Kavetsos, 2014). Moreover, typically property values increase the closer the location to a new stadium. This "proximity" effect has also been found in voting behavior for stadium referendum. For instance, Coates and Humphries (2006) found proximity to the facility increases yes vote percentages for sports facility referenda in Houston (NBA's Rockets) and Green Bay (NFL's Packers). Additionally, Dehring, Depken II, and Ward (2008) found a proximity effect to voting outcomes on the new NFL Cowboy stadium in Arlington, Texas.

However, the effect of proximity on voting outcomes is potentially more complicated than the simple direct relationship in the aforementioned studies. For instance, Ahlfeldt and Maennig (2012) find in an analysis of a professional soccer stadium in Munich that voters nearest to the proposed stadium site actually were more 
likely to vote against the referendum. This "not in my backyard" effect signifies that some voters may actually experience higher costs than others from a stadium being built (e.g. noise, pollution, congestion). The size, scale and use of the facility are also important to consider from a voter's perspective. Does the amount and or frequency of activity generated at the stadium or arena impact the voter's decision? Do voters $=$ consider venues with larger footprints and parking requirements that have a high seating capacity but low event frequency (football, soccer stadiums) different than smaller, more active, venues (arenas and baseball stadiums)?

To evaluate the impact of proximity (and other socioeconomic variables) on voting outcomes for the Seattle Seahawk Stadium data were obtained from two different sources. Precinct level voting outcomes from King County for the 1997 Special Election were obtained from the Secretary of the State of Washington, and census tract sociodemographic data were obtained from the 2000 census (Social Explorer Tables (SE), Census 2000, U.S. Census Bureau and Social Explorer). To link precinct-level voting outcomes with census track demographic information the U.S. Census Bureau in conjunetion with the State of Washington has created Voter Tabulation Districts (VTDs) that correspond to election precincts. However, election precincts do not match up directly with the underlying census tracts as some election precincts coincide with several different census tracts.

To actually match socio-demographic data with precinct voting, we utilized allocation factors for the 2000 census tracts found at the Missouri Census Data Center 
(2012). These allocation factors provide the proportion of each VTD (matched to election precincts) that overlaps different census tracts. Specifically, precinct level sociodemographic variables are created using a simple weighted average of the allocation factors and census track socioeconomic data. For example, suppose precinct A covers portions of two census tracts, $\mathrm{c}_{1}$ and $\mathrm{c}_{2}$. The weights from the Missouri Census Data $=$ Center might be $\alpha_{1}$ and $\alpha_{2}$. If Median Family Income in each of the tracts is $M_{1}$ and $M_{2}$, then our income variable for this precinct is just $M_{A}=\alpha_{1} M_{1}+\alpha_{2} M_{2}$.

Turning to specification of independent variables, we follow the general line suggested in the voting literature already cited: people vote in their own self-interest, subject to the price they will pay for the outcome. Our primary measure of net benefit impact, positive or negative, is proximity (data descriptions and descriptive statistics are in Table 1). At the precinct level, this will depend on whether the benefits from living close to the stadium are overcome by the possible negative externalities of crowded game days (simple congestion, rowdiness, drunkenness, etc.). Note that this is not necessarily about who owns businesses close to the stadium (who may drive into this area for work), it is about voters that actually live in close proximity so that your voting precinct is close to the stadium. To capture this potentially complex proximity effect, in this paper we implement two different nonlinear distance specifications: a continuous parameter and its square and a series of discrete continuous rings around the proposed stadium.

To establish distances, the boundary "shape files" for the State of Washington's 2000 Census VTDs were obtained from the National Historical Geographic Information 
(Minnesota Population Center, 2011). Using ArcGIS software, centroids were calculated for the VTDs. DISTANCE then is the driving distance (in miles) from a given precinct's centroid to the exact longitudinal coordinates of the proposed stadium site. ${ }^{3}$

The rest of the economic calculus of voting involves price and income controlling for population. We use POPULATION DENSITY (precinct population/precinct area) to $=$ represent the urbane nature of precincts. That is, people move to denser precinct areas for a variety of reasons including the level of political participation of their neighbors.

Our income measure is median precinct household INCOME. ${ }^{4}$

Price is problematic because of the multi-source revenue specification in the referendum (a variety of taxes, lottery and sales tax diversion, and tax forgiveness). For "price", we take the approach popular in the voting literature and identify groups whose welfare would be expected to change in predictable ways. ${ }^{5}$ One way or another, housing values will indicate different positions on the dimension of payment for the facility, and we choose median precinct HOME VALUE.

We also hypothesize that the portion of the precinct population OVER65 should be opposed to paying for long-term capital projects since they are more likely to enjoy only a relatively shorter period of benefits. Of course, long term capital projects (including

${ }^{3}$ We also estimated voting models with both driving time (generated in GIS) and actual linear distance as our distance measures with similar results.

${ }^{4}$ The usual multicollinearity baggage occurs here with the correlation between HOME VALUE and INCOME at 0.857 .

${ }^{5}$ Again, each of the precinct level socioeconomic variables are calculated as just described - the weighted average of "allocation factors" and the socioeconomic variable of each census tracts covered by a given precinct. 
Century Link Field) are funded using bonds which are paid over the life of the asset, making the impact of populations over 65 more complicated to predict.

The rest of the variables control for a wide variety of reasons different people vote differently. To account for differences in voting behavior by race and ethnicity we include the proportion of the population that is HISPANIC, ASIAN, and BLACK. It also can be hypothesized that the proposed stadium construction could impact property values. To account for homeownership, we include the proportion of housing units within the precinct that are RENTER occupied versus owner occupied. Education has been found in past studies to impact the voting choice, so we include the proportion of the precinct population over the age of 25 year with at least a 4-year COLLEGE degree. Voters in poorer precincts may think differently about their returns to this type of public spending as opposed to others they prefer. The proportion of the population below the federal POVERTY line is included to account for this possibility. Finally, voting can vary by occupation as well as income so we round out our variable selection with the proportion of the precinct population in WHITE COLLAR occupations. ${ }^{6}$

\section{Estimation and Results}

We investigate the Seahawk stadium referendum outcome using two different empirical specifications. One provides a specification used in past works on stadium voting in the U.S. and the other applies a specification to our stadium vote used in other,

\footnotetext{
${ }^{6}$ Even though we could calculate the dependent variable in past works, there are no other similarities in our data that allow any meaningful, direct, statistical comparisons with either Coates and Humphries (2006) or Ahlfeldt (2011).
} 
non-stadium voting studies. First, we estimate referendum-voting outcomes using the standard, linear probability (LP) specification common in the economics literature already cited on stadium voting:

$$
\text { (1) } \text { pcty }_{i}=\alpha+\beta X_{i}+\varepsilon_{i} \text {. }
$$

The dependent variable $\left(p c t y_{i}\right)$ is the percent of votes cast for the referendum in each of the $i$ precincts, $\beta$ is the vector of unknown parameters, $\mathrm{X}_{\mathrm{i}}$ is the vector of explanatory variables and $\varepsilon_{i}$ is a zero mean disturbance term. Following the literature we use a White/Huber "sandwich" correction for heteroskedasticity and, as a check on robustness, we estimate a model correcting the standard errors for spatial dependence as suggested by Conley (1999).

We also employ a "group logit" (GL) model first suggested by Theil (1970) to address heteroskedasticity directly because its form is known in our case. GL has been used to estimate vote shares for representative voter models in the political science literature ${ }^{7}$ but has yet to see use in stadium referendum analysis. In our case the form of the heteroskedasticity is known with the variance of any observation equal to:

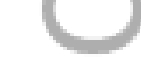
(2) $\sigma_{i}^{2}=\frac{1}{n_{i} p_{i}\left(1-p_{i}\right)}$$$
\text { (2) } \sigma_{i}^{2}=\frac{1}{n_{i} p_{i}\left(1-p_{i}\right)}
$$
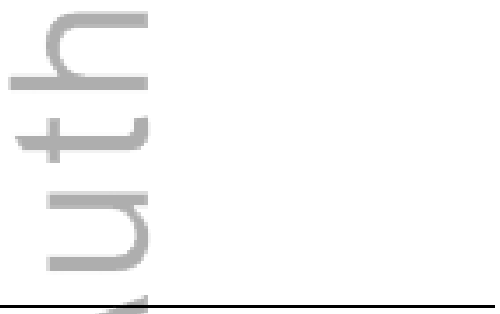

\footnotetext{
${ }^{7}$ We refer the reader to the original in Katz and King, 1999, and to Mikhailov, Niemi, and Weimer, 2002 , and for extensions in multiparty votes see Kamakura and Mazzon, 2007, and Basinger, Cann, and Ensley, 2011.
} 
where $n_{i}$ and $p_{i}$ are the number of votes cast in precinct $i$ and the proportion of yes votes in precinct $i$, respectively. GL proceeds in two stages. In the first stage, the following equation is estimated by OLS:

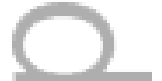

$$
\text { (3) } \log \left(\frac{p c t y_{i}}{1-p c t y_{i}}\right)=\alpha+\beta X_{i}+\varepsilon_{i} \text {. }
$$

In the second stage, the estimated coefficients from (3), designated with "hats", are used to predict the proportion of yes votes in each precinct, $\hat{p}_{i}$ :

$$
\text { (4) } \hat{p}_{i}=\frac{\exp \left(\hat{\beta}^{\prime} x_{i}\right)}{1+\exp \left(\hat{\beta}^{\prime} x_{i}\right)}
$$

The weights, which are the inverse of (2) are calculated using the predicted proportions from (4), and then (3) is run again using these analytical weights. ${ }^{8}$ GL increases efficiency by accounting for the known form of non-constant variance among the observations.

Another important empirical consideration is the proper functional form of our distance specification. To capture potential nonlinearities we implement two different distance specifications. First, we use a continuous specification incorporating both DISTANCE and its square. Second, we specify distance as a series of discrete, 5-mile continuous rings around the proposed stadium. ${ }^{9}$ When using the discrete rings specification, the omitted category is voting in areas over 35 miles from the stadium.

\footnotetext{
${ }^{8}$ Specifically, both the dependent and independent variables are multiplied by the square root of the analytical weights.

${ }^{9}$ Note that this concentric band approach is a bit different than the distance specification used in Coates and Humphreys (2006) but is close to the kilometer-wide concentric circles in Ahlfeldt and Maennig (2012).
} 
The results of our empirical models are in Table 2, containing direct estimated variables for LP and calculated marginal effects for GL. In discussing the results, it would be repetitive and clumsy to continually refer to impacts of independent variables on "the yes vote percentage for LP and the log-odds of voting yes for GL". So we refer to the impact of independent variables on "voting support" instead.

Cutting straight to the chase, we find a nonlinear impact of proximity on voting support, and some additional insight not found in earlier literature on stadium voting in the U.S. First, for LP, with distance specified continuously, voting support increased at a decreasing rate with DISTANCE. ${ }^{10}$ However, moving to the concentric circle specification of distance, much more is revealed about this non-linearity. In both LP and $\mathrm{GL}$, the parameter estimate for the closest concentric circle (0 to 5 miles) is negative and significant at the $95 \%$ level. Beyond the closest 5 miles, coefficient estimates are all positive and significant at the $95 \%$ level (except for 30 to 35 miles for LP). ${ }^{11}$

Since the omitted category is "beyond 35 miles", it is correct to interpret the negative coefficient on the closest concentric ring to mean that precincts within that distance have the lowest voting support across the entire King county, all else constant. By the same token (and again, all else constant), voting support is highest for precincts between 10 and 30 miles of the proposed site, but falls off a bit beyond 30 miles. From the estimated coefficients on the LP continuous distance specification, the maximum yes

\footnotetext{
${ }^{10}$ Note that, the point estimate for marginal effect of the continuous distance specification for GL takes only one value (i.e. there is no marginal effect for DISTANCE-squared since the marginal effect is the derivative of the probability function with respect to DISTANCE).

${ }^{11}$ These results are robust to a number of different distance bandwidth choices.
} 
vote percentage is at about 27.3 miles from the proposed site. For GL, Figure 2 presents the predicted yes vote probability conditional on distance from the stadium for the two distance specifications. The maximum is at the 25 to 30 mile category in either case. ${ }^{12}$

This nonlinear effect of proximity on voting support makes intuitive and economic sense. For those that actually live closest to the stadium, externalities and other disamenities will be largest. It is those with the easiest access to the stadium site, but somewhat removed by a short drive, that will actually enjoy the amenities without the downside. In addition, those operating businesses in close proximity to the proposed stadium site who actually do not live there, but instead populate the "easy access" areas, will be more likely to vote in support as well.

In terms of the other coefficient estimates (at the 95\% level), across all specifications, voting support increases, statistically significantly, with POPULATION DENSITY, HISPANIC, BLACK and ASIAN ethnicities, INCOME and POVERTY. Voting support also increases with OVER65. Perhaps the stadium construction was beneficial for older individuals with different time horizons. Or, perhaps individuals over 65 years old are simply just bigger football fans than previously found in the literature. Across all specifications, voting support decreases with WHITE COLLAR. This is consistent with the "blue collar" portrayal of NFL football but since we included the variable as a simple control, the impact of job type is also worthy of further research.

\footnotetext{
${ }^{12}$ The relationship in Figure 2 is derived using the sample averages of the data and, since King County voters were by and large in favor the $\mathrm{x}$-axis starts at $50 \%$. However, we are able to isolate the impact of distance and it is distinctly different that that found in the previous literature.
} 
Finally, across all specifications, RENTER is never significant and COLLEGE is only marginally significant in one model. The former could be related to the so-called “homevoter" hypothesis (Fischel, 2005; Dehring, Depken II, \& Ward, 2008). An interesting line of future work could properly test for the homevoter hypothesis using Washington State property value data.
=
Finally, note that the significance of a few variables was sensitive to model specification. The estimated coefficient on HOME VALUE is significantly positive in both LP and GL, but only for the concentric rings distance specification. Perhaps this is unsurprising since the concentric circle specification represents a "partitioning" the continuous distance specification cannot capture. BLACK is significantly positive as well in both LP and GL, but only for the continuous distance specification. We are at a loss to explain this result.

Additionally, we evaluated the robustness of our model using a LP model where we correct the standard errors for spatial dependence (Conley, 1999). ${ }^{13}$ In that model specification the significance of our distance estimates remained largely unchanged.

However, the parameters for HOME VALUE, OVER65, BLACK and POVERTY variables all were no longer significant. These variables were controls and their significance should be interpreted cautiously in the first place. Additionally, these results suggest that more work should be done to evaluate the proper use of spatial analysis in

\footnotetext{
${ }^{13}$ For this model we used a distance cutoff of 5 miles in each direction (north, south, east and west), thus a correlated landmass of 100 square miles.
} 
voting behavior studies, both in terms of adjusting standard errors and in terms of including spatial weighting matrices into the empirical model.

One additional potential problem with our analysis concerns any bias that might be caused by unobserved population/location characteristics correlated with distance to the stadium. To evaluate this possibility we provide a "falsification test" by estimating the GL model on two joint resolutions that appeared on the 1997 Washington state general election ballot. ${ }^{14}$ The question in Joint Resolution 4208 read, "Shall the constitution be amended to permit voter-approved school district levies to run for an optional four-year period, rather than the current two-year maximum?" The question in Joint Resolution 4209 was, "Shall the Constitution be amended to permit local governments to make loans for the conservation of the more efficient use of storm water or sewer services?". If distance is significant in the explanation of voting in these two joint resolutions that seemingly have no differential impacts by location, and in the same way distance is significant in our case, then it is likely that the stadium distance effect we find for our case actually is driven by unobserved characteristics.

The results of the falsification test are in Table 3. Cutting straight to the chase, it is clear that distance matters in a fundamentally different way, for both joint resolutions than it did for our case, Referendum 48. Specifically, the distance ring closest to the stadium, which received the lowest support for our case, received the highest support in the joint resolutions. More generally, both joint resolutions were characterized by linear

\footnotetext{
${ }^{14}$ We would like to thank an anonymous referee for making this suggestion.
} 
negative voting behavior as distance increases from the stadium site. Thus, while there is a significant spatial relationship in both joint resolutions where none was expected, it is fundamentally different than in the case of our Referendum $48 .{ }^{15}$ This falsification test suggests that our findings on the importance and behavior of distance in the determination of voting are not due to unobserved other voting determinants.

\section{Conclusions.}

On June 17, 1997 voters in the state of Washington passed Referendum 48 with 51.1 percent of the popular vote. Qwest Field (now CenturyLink Field) was eventually constructed and professional football remained in the State of Washington. Eventual owner Paul Allen purchased a time sensitive option to buy the Seahawks, spent millions on advertising, and covered the cost of the special election. The election was clearly characterized by the threat that the team would be lost in the event of referendum failure by both Allen and then-owner Ken Behring.

In a precinct-level representative voter model, we discover a number of interesting things. Foremost, we find a nonlinear impact of distance on voting outcomes. Notably, we find that voter support was lowest (all else constant) in closest proximity to the proposed site (0-5 miles) voter support was highest from 10 to 30 miles from the proposed site (the largest positive marginal impact was at 27.3 miles in the continuous distance specification), and then fell off again beyond 30 miles. This nonlinear proximity effect is different than in previous work on sports referenda in the U.S. and signifies that,

${ }^{15}$ Note that within 20 miles from the stadium there is a significant spatial relationship for all three referenda, but only referenda 48 had a spatial relationship from 20 to 35 miles away from the stadium. 
in terms of close proximity to a stadium, voters may actually experience higher costs (e.g. noise, pollution, congestion). Consistent with findings by Ahlfeldt and Meannig (2012) on stadium voting in Europe, professional football stadiums in the United States may also exhibit "not in my backyard" voting behavior. Moreover, this is consistent with voting behavior on other public projects such as national forests (Kim \& Johnson, 2002; Ham, Champ, Loomis, \& Reich, 2012). However, the non-linear behavior beyond close proximity is a novel finding.

Additional socio-demographic variables impact voting as they have in past studies with the exception that the odds of voting yes increased as the proportion of the precinct population over age 65 increased. In addition to this interesting outcome, the preference formation of minority voters, the poor, and white-collar workers deserve focus in subsequent research. Some of these results are also sensitive to empirical specification.

Further on the issue of empirical specification, and without any formal means to conclude one model is "better" than another overall, we can only observe the following in comparing the linear probability model and the group logit model. On the same data, the group logit has higher $\mathrm{R}^{2}(8 \%-11 \%$, depending on the specification of distance) as well as the efficiency gain from directly accounting for the form of non-constant variance.

However, $\mathrm{R}^{2}$ cannot be a deciding factor since the dependent variables are different in the linear probability and group logit models. In addition, the significance of the portion of the precinct population living below the poverty line comes into play only for the group logit model. 


\section{References}

Agostini, S.J., J.M. Quigley, and E. Smolensky. "Stickball in San Francisco," in Sports, Jobs and Taxes: The Economic Impact of Sports Teams and Stadiums, edited by

R.G. Noll and A. Zimbalist, Washington, D. C.: Brookings Institution, 1997, 385426.

Ahlfeldt, G.M. "Blessing or Curse? Appreciation, Amenities and Resistance to Urban Renewal." Regional Science \& Urban Economics, 41(1), 2011, 32-45.

Ahlfeldt, G.M, and G. Kavetsos. "Form or function? The Effect of New Sports Stadia on Property Prices in London." Journal of the Royal Statistical Society: Series A (Statistics in Society), 177 (1), 2014, 169-190.

Ahlfeldt, G.M., and W. Maennig. "Voting on a NIMBY Facility Proximity Cost of An “Iconic" Stadium." Urban Affairs Review, 48 (2), 2012, 205-237.

Basinger, S.J., D.M. Cann, and M.J. Ensley. "Voter Response to Congressional Campaigns: New Techniques for Analyzing Aggregate Electoral Behavior.” Public Choice, 150(3-4), 2012, 771-792.

Bergstrom, T.C., and R.P. Goodman. "Private Demands for Public Goods." American Economic Review, 63(3), 1973, 280-296.

Borcherding, T.E., and R.T. Deacon. "The Demand for the Services of Non-Federal Governments." American Economic Review, 62(5), 1972. 891-901.

Brown, C., and D.M. Paul. "Local Organized Interests and the 1996 Cincinnati Sports Stadia Tax Referendum.” Journal of Sport and Social Issues, 23(2), 1999, 218-237. 
Chang, C., and G.K. Turnbull. "Bureaucratic Behavior in the Local Public Sector: A Revealed Preference Approach." Public Choice, 113(1-2), 2002, 191-210.

Coates, D., and B.R. Humphreys. "Proximity Benefits and Voting on Stadium and Arena Subsidies." Journal of Urban Economics, 59(2), 2006, 285-299.

Conley, T.G. "GMM estimation with cross sectional dependence." Journal of $=$ Econometrics, 92(1), 1999, 1-45.

Deacon, R., and P. Shapiro. "Private Preference for Collective Goods Revealed through Voting on Referenda." American Economic Review, 65(5), 1975, 943-955.

Dehring, C.A., C.A. Depken, II, and M.R. Ward. “The Impact Of Stadium Announcements On Residential Property Values: Evidence From A Natural Experiment In Dallas-Fort Worth.” Contemporary Economic Policy, 25(4), 2007, $627-638$.

Dehring, C.A., C.A. Depken, II, and M.R. Ward. “A Direct Test of the Homevoter Hypothesis." Journal of Urban Economics, 64(1), 2008, 155-170.

Depken, C.A., II. "Fan Loyalty and Stadium Funding in Professional Baseball.” Journal of Sports Economics, 1(2), 2000, 124-148.

Downs, A. An Economic Theory of Democracy. New York, NY: Harper and Row, 1957.

Feng, Xia, and B.R. Humphreys. "The Impact Of Professional Sports Facilities On Housing Values: Evidence From Census Block Group Data." City, Culture and Society, 3(3), 2012, 189-200.

This article is protected by copyright. All rights reserved. 
Filimon, R., T. Romer, and H. Rosenthal. "Asymmetric Information and Agenda Control: The Bases of Monopoly Power in Public Spending." Journal of Public Economics, 17(1), 1982, 51-70.

Fischel, W.A. The Homevoter Hypothesis: How Home Values Influence Local Government Taxation, School Finance, and Land-Use Policies. Cambridge, MA: $=$

Harvard University Press, 2005.

Fort, R. "The Median Voter, Setters, and Non-repeated Construction Bond Issues." Public Choice, 56(3), 1988, 213-231.

Fort, R. "Direct Democracy and the Stadium Mess," in Sports, Jobs and Taxes: The Economic Impact of Sports Teams and Stadiums, edited by R.G. Noll and A. Zimbalist, Washington, D. C.: Brookings Institution, 1997, 146-177.

Fort, R.D. "Stadium Votes, Market Power and Politics." University of Toledo Law Review, 30, 1999, 419-441.

Ham, C., P.A. Champ, J.B. Loomis, and R.M. Reich. “Accounting for Heterogeneity of Public Lands in Hedonic Property Models.” Land Economics, 88(3), 2012, 444-456.

Hoxby, C.M. "Does Competition among Public Schools Benefit Students and Taxpayers?" American Economic Review, 90(5), 2000, 1209-1238.

Kamakura, W.A., and J.A. Mazzon. “Accounting for Voter Heterogeneity within and across Districts with a Factor-Analytic Voter-Choice Model.” Political Analysis, $15(1), 2007,67-84$ 
Katz, J.N., and G. King. "A Statistical Model for Multiparty Electoral Data.” American Political Science Review, 93(1), 1999, 15-32.

Kim, Y.S., and R.L. Johnson. "The Impact of Forests and Forest Management on Neighboring Property Values.” Society \& Natural Resources, 15(10), 2002, 887901.

Mikhailov, N., R.G. Niemi, and D.L. Weimer. "Application of Theil Group Logit Methods to District-level Vote Shares: Tests of Prospective and Retrospective Voting in 1991, 1993, and 1997 Polish Elections.” Electoral Studies, 21(4), 2002, 631-648.

Minnesota Population Center. National Historical Geographic Information System:

Version 2.0. Minneapolis, MN: University of Minnesota, 2011.

Missouri Census Data Center. MABLE/Geocorr2k: Geographic Correspondence Engine with Census 2000 Geography, 2012. Last accessed November 13, 2012 at: http://mcdc.missouri.edu/websas/geocorr2k.html.

Romer, T., and H. Rosenthal. "Political Resource Allocation, Controlled Agendas, and the Status Quo.” Public Choice, 33(4), 1978, 27-43.

Secretary of the State of Washington. Official Washington's Voter Pamphlet, 1997.

Secretary of the State of Washington. "Elections \& Voting," 2009. URL last accessed March 11,

2009: http://www.secstate.wa.gov/elections/results report.aspx? $\mathrm{e}=11 \& \mathrm{c}=\& \mathrm{c} 2=\& \mathrm{t}=$ $\& \mathrm{t} 2=\& \mathrm{p}=\& \mathrm{p} 2=\& \mathrm{y}=$

This article is protected by copyright. All rights reserved. 
Theil, H. "On the Estimation of Relationships Involving Qualitative Variables."

American Journal of Sociology, 76(1), 1970, 103-154.

Tu, C. C. "How Does A New Sports Stadium Affect Housing Values? The Case Of " Fedex Field." Land Economics, 81(3), 2005, 379-395.
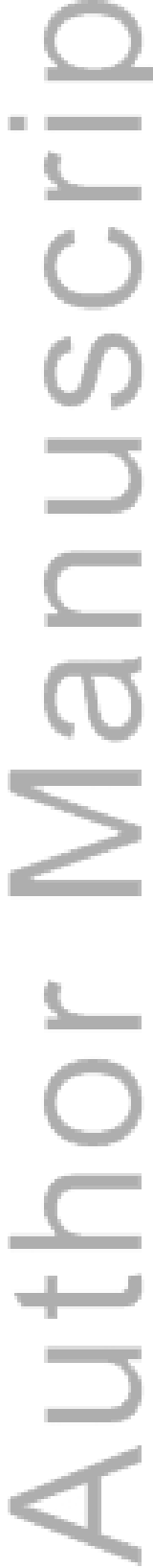

This article is protected by copyright. All rights reserved. 
Figure 1. Referendum Bill 48: Geographic Voting Outcomes.

\section{Referendum 48 Voting Outcomes King County, Washington}

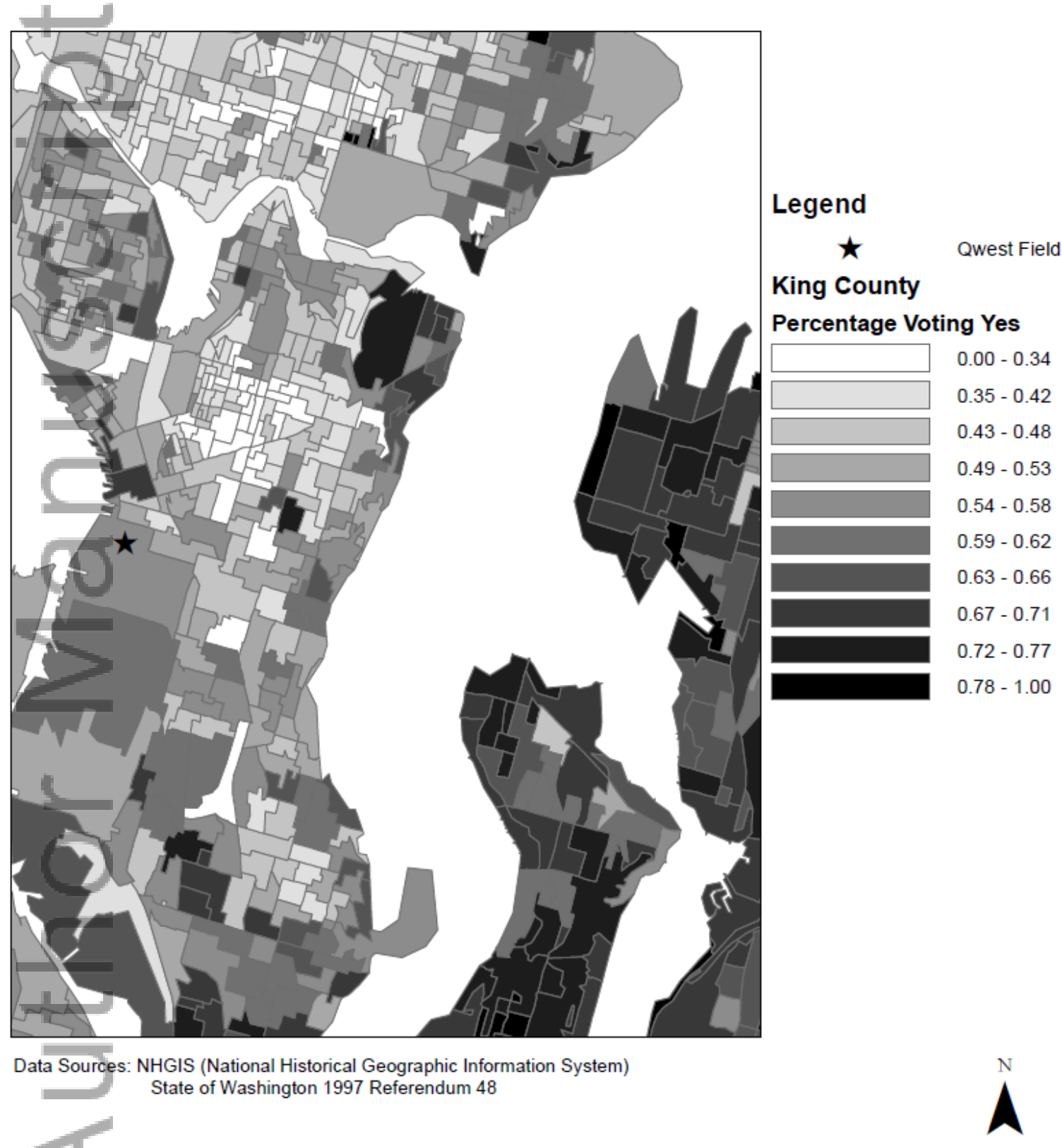

This article is protected by copyright. All rights reserved. 


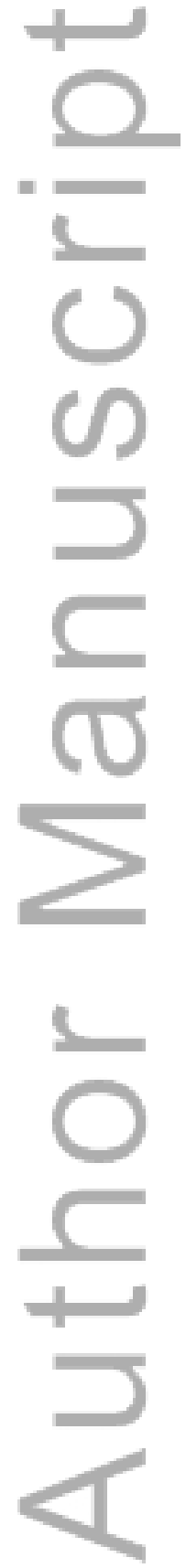

This article is protected by copyright. All rights reserved. 
Figure 2. Predicted odds of voting yes, conditional on distance.

Continuous Distance Specification

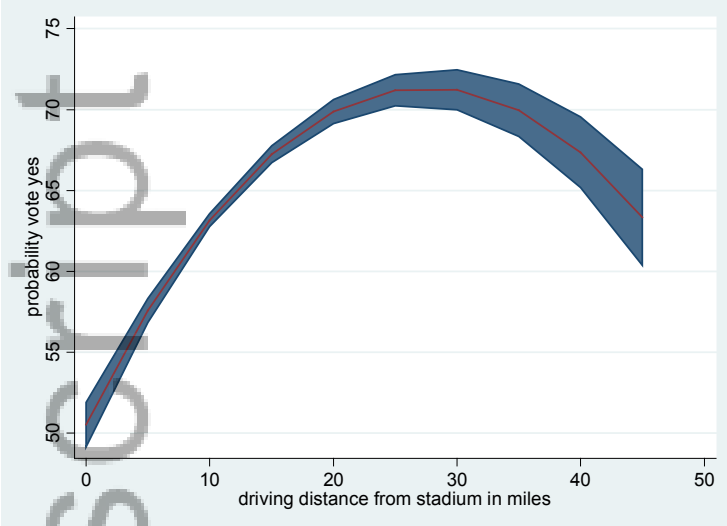

5-Mile Contiguous Ring Specification

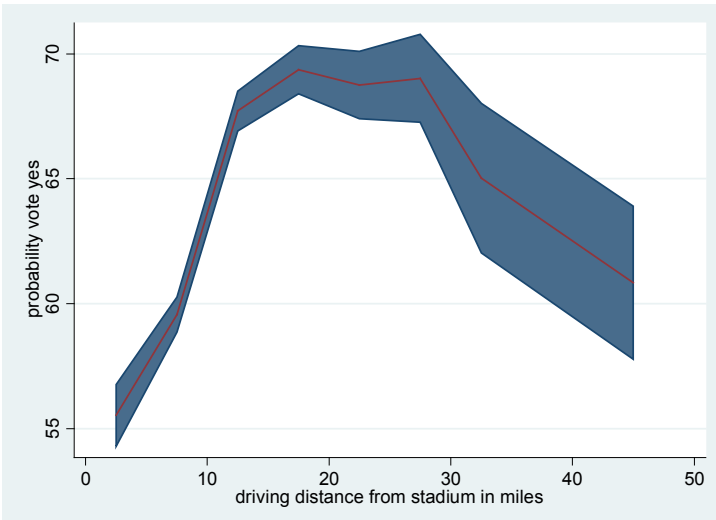

Notes: Probabilities of yes votes were predicted using the mean of all other covariates. Blue band indicates a 95\% confidence interval.

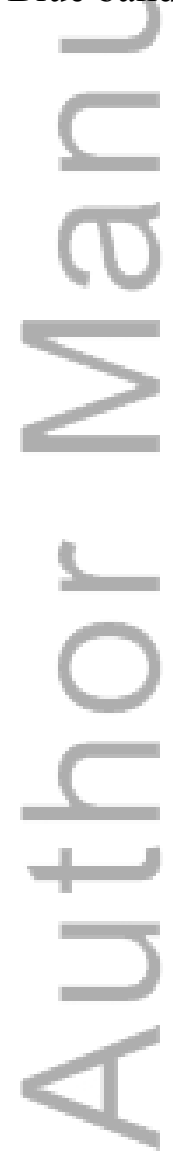


Table 1. Variables and Descriptive Statistics (2,500 observations).

\begin{tabular}{|c|c|c|c|c|c|}
\hline Variable & Explanation & Min & $\underline{\operatorname{Max}}$ & Mean & $\underline{\mathrm{SD}}$ \\
\hline VOTES & Total votes cast & 2.00 & 290.00 & 108.75 & 38.70 \\
\hline$\%$ YES & (Yes votes /VOTES)*100 & 8.33 & 90.00 & 57.92 & 10.62 \\
\hline DISTANCE & $\begin{array}{l}\text { Driving distance from the } \\
\text { stadium }\end{array}$ & 0.31 & 75.11 & 12.40 & 8.09 \\
\hline $\begin{array}{l}\text { POPULATION } \\
\text { DENSITY }\end{array}$ & $\begin{array}{l}\text { Population divided by } \\
\text { landmass }\end{array}$ & 0.00 & 101.17 & 2.76 & 3.92 \\
\hline HOME VALUE & $\begin{array}{l}\text { Median Owner-Occupied } \\
\text { home value divided by } 1000\end{array}$ & 23.40 & 781.00 & 255.10 & 104.39 \\
\hline INCOME & $\begin{array}{l}\text { Median household family } \\
\text { income divided by } 1,000\end{array}$ & 16.69 & 149.64 & 68.35 & 20.35 \\
\hline OVER65 & $\%$ of population over 65 & 1.43 & 43.51 & 11.40 & 4.96 \\
\hline HISPANIC & $\%$ of population Hispanic & 1.18 & 37.10 & 5.08 & 3.51 \\
\hline ASIAN & $\%$ of population Asian & 0.34 & 58.05 & 10.18 & 8.45 \\
\hline BLACK & $\%$ of population Black & 0.12 & 50.06 & 5.02 & 7.09 \\
\hline RENTER & $\begin{array}{l}\% \text { of POPULATION in } \\
\text { renter occupied housing }\end{array}$ & 2.89 & 97.32 & 37.64 & 21.18 \\
\hline COELEGE & $\begin{array}{l}\% \text { of POPULATION with at } \\
\text { least a four-year degree }\end{array}$ & 2.12 & 51.15 & 27.79 & 9.77 \\
\hline & $\begin{array}{l}\% \text { of POPULATION below } \\
\text { federal poverty line }\end{array}$ & 0.20 & 48.73 & 8.20 & 6.22 \\
\hline $\begin{array}{l}\text { WHITE } \\
\text { COLLAR }\end{array}$ & $\begin{array}{l}\% \text { of POPULATION in } \\
\text { white collar occupations }\end{array}$ & 15.53 & 68.66 & 45.03 & 10.60 \\
\hline
\end{tabular}

Sources: Voting data are from the Secretary of the State of Washington (2007).

Demographic data are from U.S. Census Bureau (2000).

Note: Since estimation cannot happen if precincts actually have $0 \%$ or $100 \%$ YES, one precinct was eliminated from the data (100\% YES).

This article is protected by copyright. All rights reserved. 
Table 2. Empirical Results.

\begin{tabular}{|c|c|c|c|c|}
\hline & \multicolumn{2}{|c|}{ Linear Probability Model } & \multicolumn{2}{|c|}{ Group Logit } \\
\hline$\underline{\text { Variable }}$ & $\begin{array}{c}\text { Continuous Distance } \\
\text { Variables }\end{array}$ & $\begin{array}{c}\text { Discrete } \\
\text { Distance Rings }\end{array}$ & $\begin{array}{c}\text { Continuous Distance } \\
\text { Variables }\end{array}$ & $\begin{array}{c}\text { Discrete } \\
\text { Distance Rings }\end{array}$ \\
\hline Distance & $\begin{array}{c}1.257 * * * \\
(0.133) \\
\end{array}$ & -- & $\begin{array}{c}0.803^{* * *} \\
(0.044) \\
\end{array}$ & -- \\
\hline Distance-squared & $\begin{array}{c}-0.022 * * * \\
(0.004)\end{array}$ & -- & -- & \\
\hline $\begin{array}{l}0 \text { to } 5 \text { miles from } \\
\text { stadium }\end{array}$ & -- & $\begin{array}{c}-4.666 * * * \\
(1.527)\end{array}$ & -- & $\begin{array}{c}-5.267 * * * \\
(1.763)\end{array}$ \\
\hline $\begin{array}{c}5 \text { to } 10 \text { miles from } \\
\text { stadium }\end{array}$ & -- & $\begin{array}{l}-0.235 \\
(1.361) \\
\end{array}$ & -- & $\begin{array}{l}-1.276 \\
(1.626) \\
\end{array}$ \\
\hline $\begin{array}{l}10 \text { to } 15 \text { miles from } \\
\text { stadium }\end{array}$ & -- & $\begin{array}{c}6.986 * * * \\
(1.361) \\
\end{array}$ & -- & $\begin{array}{c}6.818 * * * \\
(1.620) \\
\end{array}$ \\
\hline $\begin{array}{c}15 \text { to } 20 \text { miles from } \\
\text { stadium }\end{array}$ & -- & $\begin{array}{c}8.228 * * * \\
(1.343)\end{array}$ & -- & $\begin{array}{c}8.464 * * * \\
(1.582)\end{array}$ \\
\hline $\begin{array}{c}20 \text { to } 25 \text { miles from } \\
\text { stadium }\end{array}$ & -- & $\begin{array}{c}7.160 * * * \\
(1.346) \\
\end{array}$ & -- & $\begin{array}{c}7.848 * * * \\
(1.581) \\
\end{array}$ \\
\hline $\begin{array}{c}25 \text { to } 30 \text { miles from } \\
\text { stadium }\end{array}$ & -- & $\begin{array}{c}7.527 * * * \\
(1.451) \\
\end{array}$ & -- & $\begin{array}{c}8.114^{* * *} \\
(1.615)\end{array}$ \\
\hline $\begin{array}{c}30 \text { to } 35 \text { miles from } \\
\text { stadium }\end{array}$ & -- & $\begin{array}{l}3.232 * * \\
(1.631)\end{array}$ & -- & $\begin{array}{c}4.142 * * \\
(1.978)\end{array}$ \\
\hline Population Density & $\begin{array}{c}0.232 * * * \\
(0.088)\end{array}$ & $\begin{array}{c}0.240 * * * \\
(0.084)\end{array}$ & $\begin{array}{l}0.170 * * \\
(0.066)\end{array}$ & $\begin{array}{l}0.155^{*} * \\
(0.066)\end{array}$ \\
\hline Home Value & $\begin{array}{c}0.005 \\
(0.005)\end{array}$ & $\begin{array}{c}0.012 * * * \\
(0.005)\end{array}$ & $\begin{array}{c}0.007 \\
(0.005)\end{array}$ & $\begin{array}{c}0.014 * * * \\
(0.005)\end{array}$ \\
\hline Over 65 & $\begin{array}{c}0.262 * * * \\
(0.045) \\
\end{array}$ & $\begin{array}{c}0.169 * * * \\
(0.046) \\
\end{array}$ & $\begin{array}{c}0.295 * * * \\
(0.043) \\
\end{array}$ & $\begin{array}{c}0.217 * * * \\
(0.044) \\
\end{array}$ \\
\hline Hispanic & $\begin{array}{c}0.558 * * * \\
(0.092)\end{array}$ & $\begin{array}{c}0.437 * * * \\
(0.086)\end{array}$ & $\begin{array}{c}0.695 * * * \\
(0.084)\end{array}$ & $\begin{array}{c}0.615 * * * \\
(0.085)\end{array}$ \\
\hline Asian & $\begin{array}{c}0.322 * * * \\
(0.028) \\
\end{array}$ & $\begin{array}{c}0.260 * * * \\
(0.027) \\
\end{array}$ & $\begin{array}{c}0.398 * * * \\
(0.028) \\
\end{array}$ & $\begin{array}{c}0.338 * * * \\
(0.028) \\
\end{array}$ \\
\hline Black & $\begin{array}{c}0.101 * * * \\
(0.038)\end{array}$ & $\begin{array}{c}0.082 * * \\
(0.039) \\
\end{array}$ & $\begin{array}{c}0.122 * * * \\
(0.038)\end{array}$ & $\begin{array}{l}0.078 * * \\
(0.039)\end{array}$ \\
\hline Renter & $\begin{array}{c}0.002 \\
(0.017) \\
\end{array}$ & $\begin{array}{l}-0.009 \\
(0.017)\end{array}$ & $\begin{array}{c}0.023 \\
(0.016)\end{array}$ & $\begin{array}{c}0.003 \\
(0.017) \\
\end{array}$ \\
\hline College & $\begin{array}{c}0.038 \\
(0.047)\end{array}$ & $\begin{array}{l}-0.085^{*} \\
(0.046)\end{array}$ & $\begin{array}{c}0.034 \\
(0.046)\end{array}$ & $\begin{array}{l}-0.071 \\
(0.046)\end{array}$ \\
\hline Poverty & $\begin{array}{c}-0.152 * * \\
(0.064)\end{array}$ & $\begin{array}{c}-0.148 * * \\
(0.064)\end{array}$ & $\begin{array}{c}-0.244 * * * \\
(0.055)\end{array}$ & $\begin{array}{c}-0.242 * * * \\
(0.055)\end{array}$ \\
\hline White Collar & $\begin{array}{c}-0.165 * * * \\
(0.036)\end{array}$ & $\begin{array}{c}-0.149 * * * \\
(0.036)\end{array}$ & $\begin{array}{c}-0.191 * * * \\
(0.038)\end{array}$ & $\begin{array}{c}-0.174 * * * \\
(0.038)\end{array}$ \\
\hline Income & $\begin{array}{c}0.215^{* * * *} \\
(0.031)\end{array}$ & $\begin{array}{c}0.195 * * * \\
(0.031)\end{array}$ & $\begin{array}{c}0.248 * * * \\
(0.030)\end{array}$ & $\begin{array}{c}0.218 * * * \\
(0.030)\end{array}$ \\
\hline Can & $\begin{array}{c}28.418 * * * \\
(2.503)\end{array}$ & $\begin{array}{c}1.199 * * * \\
(2.197) \\
\end{array}$ & -- & -- \\
\hline Observations & 2500 & 2500 & 2500 & 2500 \\
\hline
\end{tabular}


\begin{tabular}{l|l|l|l|l} 
R-Squared & 0.355 & 0.379 & $0.393^{\mathrm{a}}$ & $0.407^{\mathrm{a}}$
\end{tabular}

Notes: Standard errors are in parentheses. $* * *$ Significant at $99 \%$ level. $* *$ Significant at 95\% level. *Significant at 90\% level. Marginal effects are reported for the group logit models. ${ }^{a}$ indicates adjusted R-squared.

Table 3. Falsification test

\begin{tabular}{|c|c|c|c|}
\hline Variable & Ref 48 & 4208 & 4209 \\
\hline 0 to 5 miles from stadium & $\begin{array}{c}-5.267 * * * \\
(1.763) \\
\end{array}$ & $\begin{array}{c}12.451 * * * \\
(1.391) \\
\end{array}$ & $\begin{array}{c}8.177 * * * \\
(1.202) \\
\end{array}$ \\
\hline 5 to 10 miles from stadium & $\begin{array}{l}-1.276 \\
(1.626)\end{array}$ & $\begin{array}{c}10.427 * * * \\
(1.284)\end{array}$ & $\begin{array}{c}6.282 * * * \\
(1.105)\end{array}$ \\
\hline to 15 miles from stadium & $\begin{array}{c}6.818 * * * \\
(1.620) \\
\end{array}$ & $\begin{array}{c}4.973 * * * \\
(1.286) \\
\end{array}$ & $\begin{array}{c}3.116^{* * * *} \\
(1.108) \\
\end{array}$ \\
\hline to 20 miles from stadium & $\begin{array}{c}8.464 * * * \\
(1.582)\end{array}$ & $\begin{array}{c}2.922 * * \\
(1.250)\end{array}$ & $\begin{array}{l}1.876^{*} \\
(1.075) \\
\end{array}$ \\
\hline 20 to 25 miles from stadium & $\begin{array}{c}7.848 * * * \\
(1.581) \\
\end{array}$ & $\begin{array}{c}1.373 \\
(1.247) \\
\end{array}$ & $\begin{array}{c}0.773 \\
(1.071) \\
\end{array}$ \\
\hline 25 to 30 miles from stadium & $\begin{array}{c}8.114 * * * \\
(1.615)\end{array}$ & $\begin{array}{c}1.683 \\
(1.277) \\
\end{array}$ & $\begin{array}{l}1.340 \\
(1.090)\end{array}$ \\
\hline 30 to 35 miles from stadium & $\begin{array}{l}4.142 * * \\
(1.978)\end{array}$ & $\begin{array}{l}-1.693 \\
(1.565)\end{array}$ & $\begin{array}{c}0.004 \\
(1.337)\end{array}$ \\
\hline Population Density & $\begin{array}{l}0.155^{* *} \\
(0.066) \\
\end{array}$ & $\begin{array}{c}0.078 \\
(0.054) \\
\end{array}$ & $\begin{array}{c}0.117 * * \\
(0.051) \\
\end{array}$ \\
\hline Home Value & $\begin{array}{c}0.014 * * * \\
(0.005)\end{array}$ & $\begin{array}{l}-0.004 \\
(0.004)\end{array}$ & $\begin{array}{c}0.000 \\
(0.004)\end{array}$ \\
\hline Over 65 & $\begin{array}{c}0.217 * * * \\
(0.044)\end{array}$ & $\begin{array}{c}-0.082 * * \\
(0.037) \\
\end{array}$ & $\begin{array}{c}-0.075 * * \\
(0.033) \\
\end{array}$ \\
\hline Hispanic & $\begin{array}{c}0.615 * * * \\
(0.085)\end{array}$ & $\begin{array}{c}-0.185^{* * * *} \\
(0.067)\end{array}$ & $\begin{array}{c}-0.172 * * * \\
(0.058)\end{array}$ \\
\hline Asian & $\begin{array}{c}0.338 * * * \\
(0.028)\end{array}$ & $\begin{array}{c}-0.104 * * * \\
(0.023)\end{array}$ & $\begin{array}{c}-0.072 * * * \\
(0.020)\end{array}$ \\
\hline Black & $\begin{array}{c}0.078 * * \\
(0.039)\end{array}$ & $\begin{array}{c}0.075 * * \\
(0.032)\end{array}$ & $\begin{array}{c}-0.067 * * \\
(0.028)\end{array}$ \\
\hline Renter & $\begin{array}{c}0.003 \\
(0.017) \\
\end{array}$ & $\begin{array}{l}0.032 * * \\
(0.014)\end{array}$ & $\begin{array}{c}0.043 * * * \\
(0.012)\end{array}$ \\
\hline College & $\begin{array}{l}-0.071 \\
(0.046)\end{array}$ & $\begin{array}{c}0.227 * * * \\
(0.038)\end{array}$ & $\begin{array}{c}0.290 * * * \\
(0.034)\end{array}$ \\
\hline Poverty & $\begin{array}{c}-0.242 * * * \\
(0.055) \\
\end{array}$ & $\begin{array}{c}0.199 * * * \\
(0.046)\end{array}$ & $\begin{array}{c}0.205^{* * * *} \\
(0.042)\end{array}$ \\
\hline White Collar & $-0.174 * * *$ & $0.487 * * *$ & $0.417 * * *$ \\
\hline
\end{tabular}

This article is protected by copyright. All rights reserved. 


\begin{tabular}{|c|c|c|c|}
\hline Income & $(0.038)$ & $(0.032)$ & $(0.029)$ \\
\hline Observations & $\begin{array}{c}0.218^{* * *} \\
(0.030)\end{array}$ & $\begin{array}{c}0.008 \\
(0.026)\end{array}$ & $\begin{array}{c}-0.026 \\
(0.023)\end{array}$ \\
\hline R-Squared & 2500 & 2488 & 2488 \\
\hline & $0.4090^{\mathrm{a}}$ & $0.653^{\mathrm{a}}$ & $0.6355^{\mathrm{a}}$ \\
\hline
\end{tabular}

Notes: Standard errors are in parentheses. ${ }^{* * *}$ Significant at $99 \%$ level. ${ }^{* *}$ Significant at $95 \%$ level. *Significant at $90 \%$ level. Marginal effects are reported for the group logit models. ${ }^{a}$ indicates adjusted R-squared.

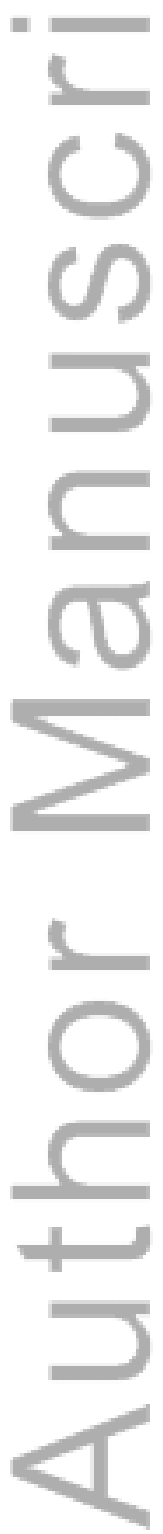

This article is protected by copyright. All rights reserved. 


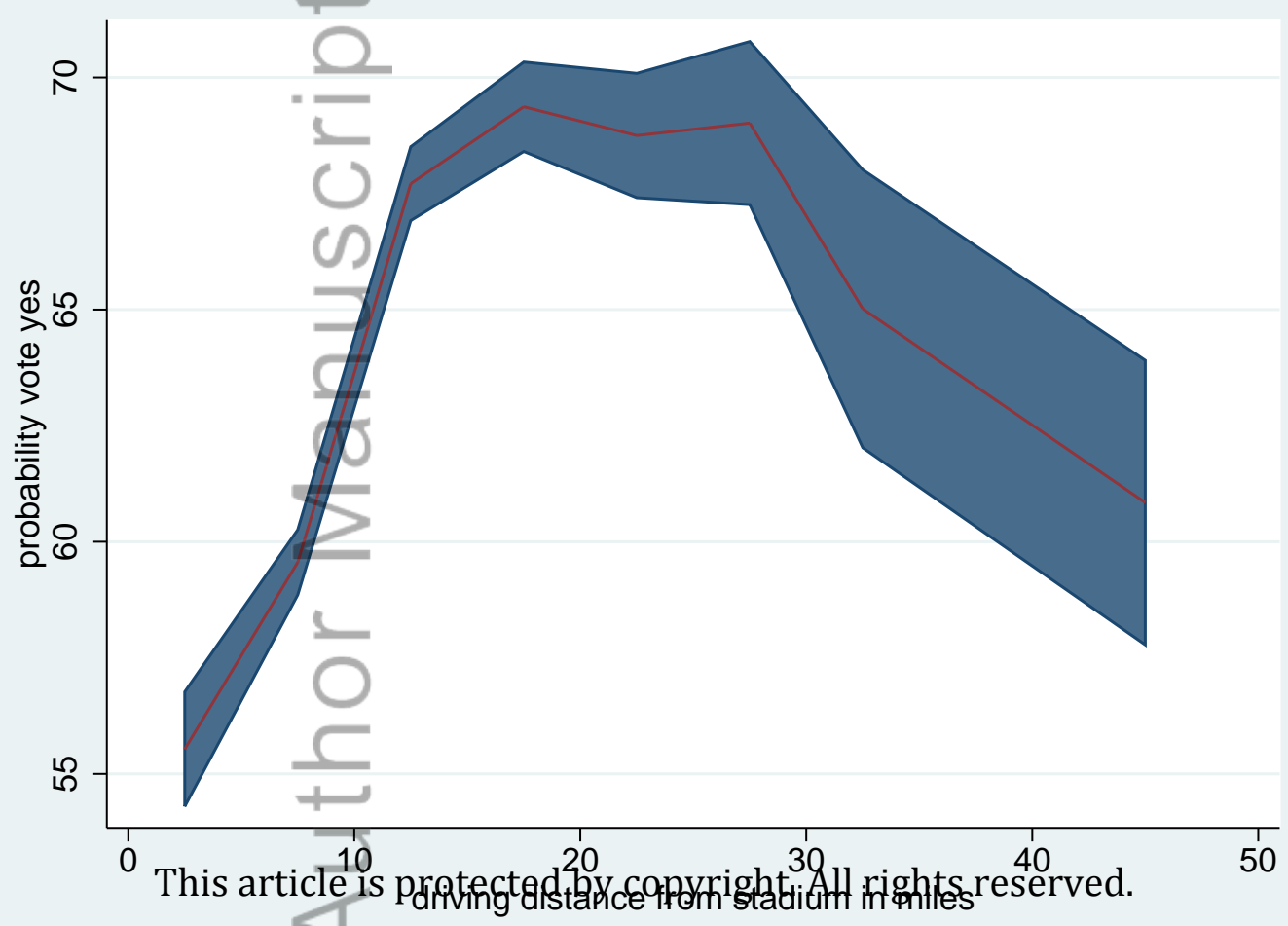




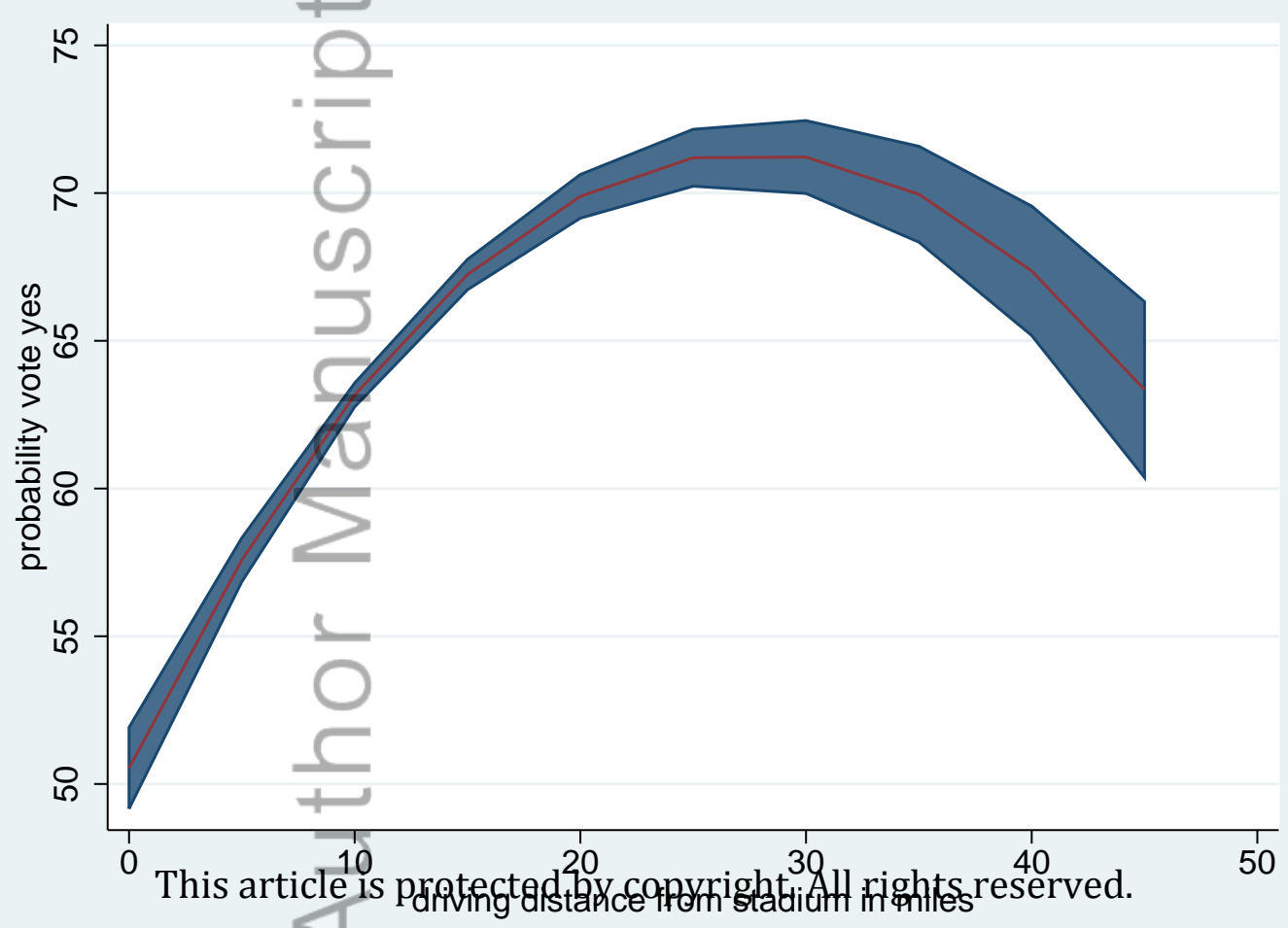




\section{Referendum 48 Voting Outcomes King County, Washington}

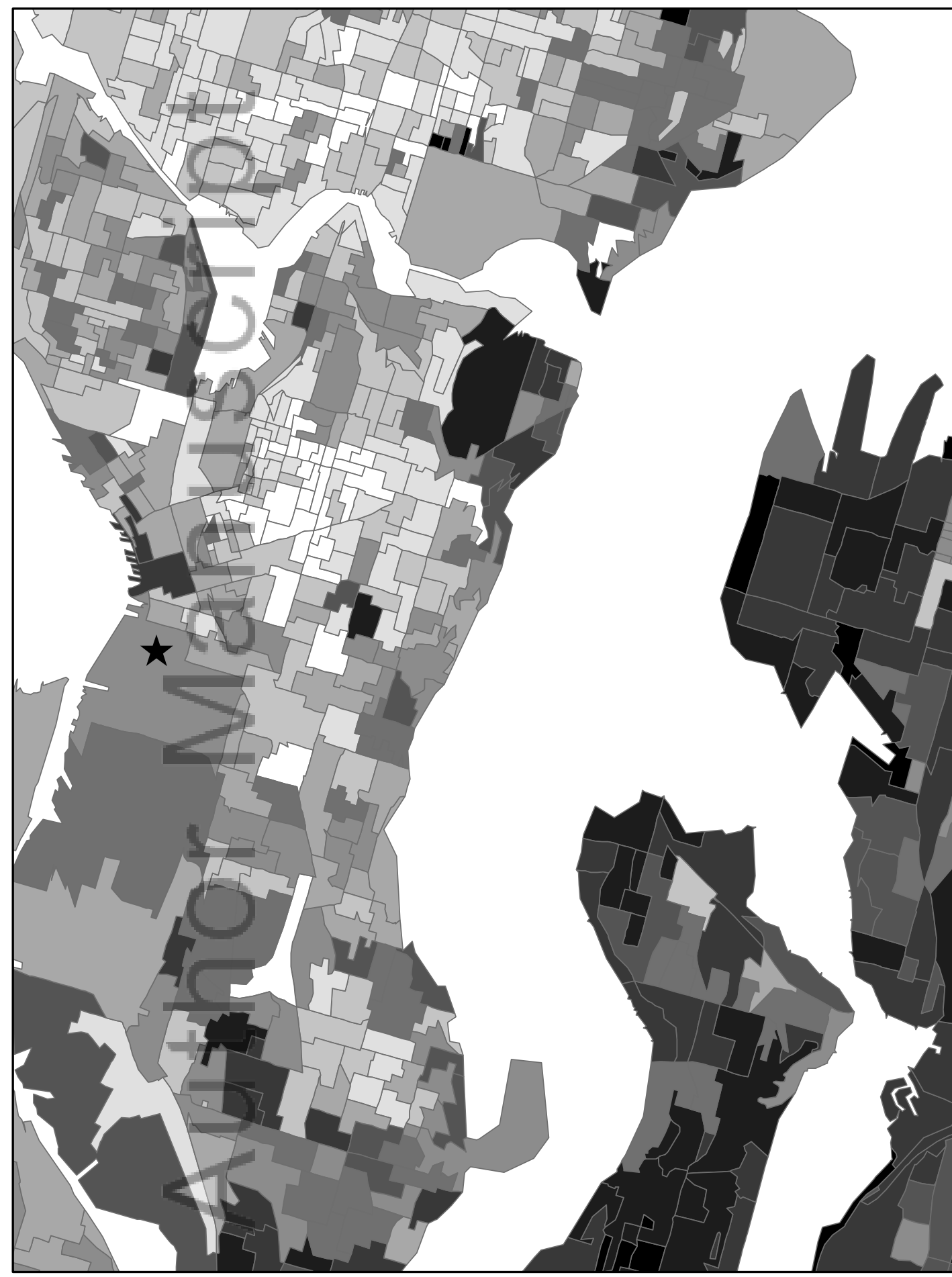

Legend

King County Qwest Field

\section{Percentage Voting Yes}

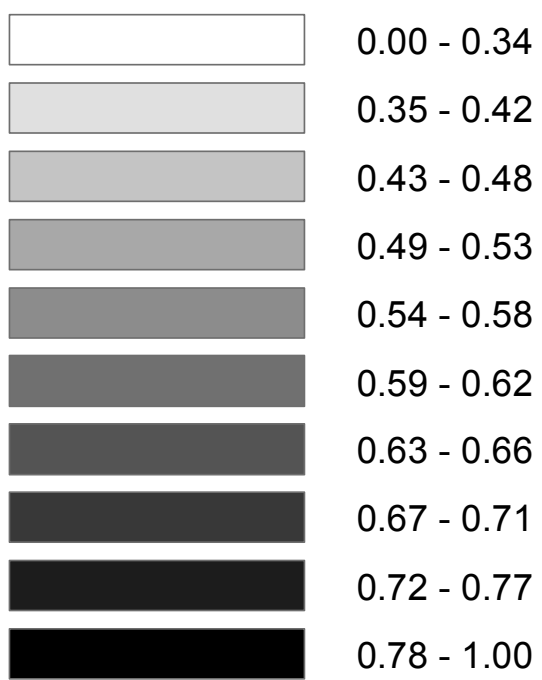

Data Sources: NHGIS (National Historical Geographic Information System) State of Washington 1997 Referendum 48 


\section{Referendum 48 Voting Outcomes King County, Washington}

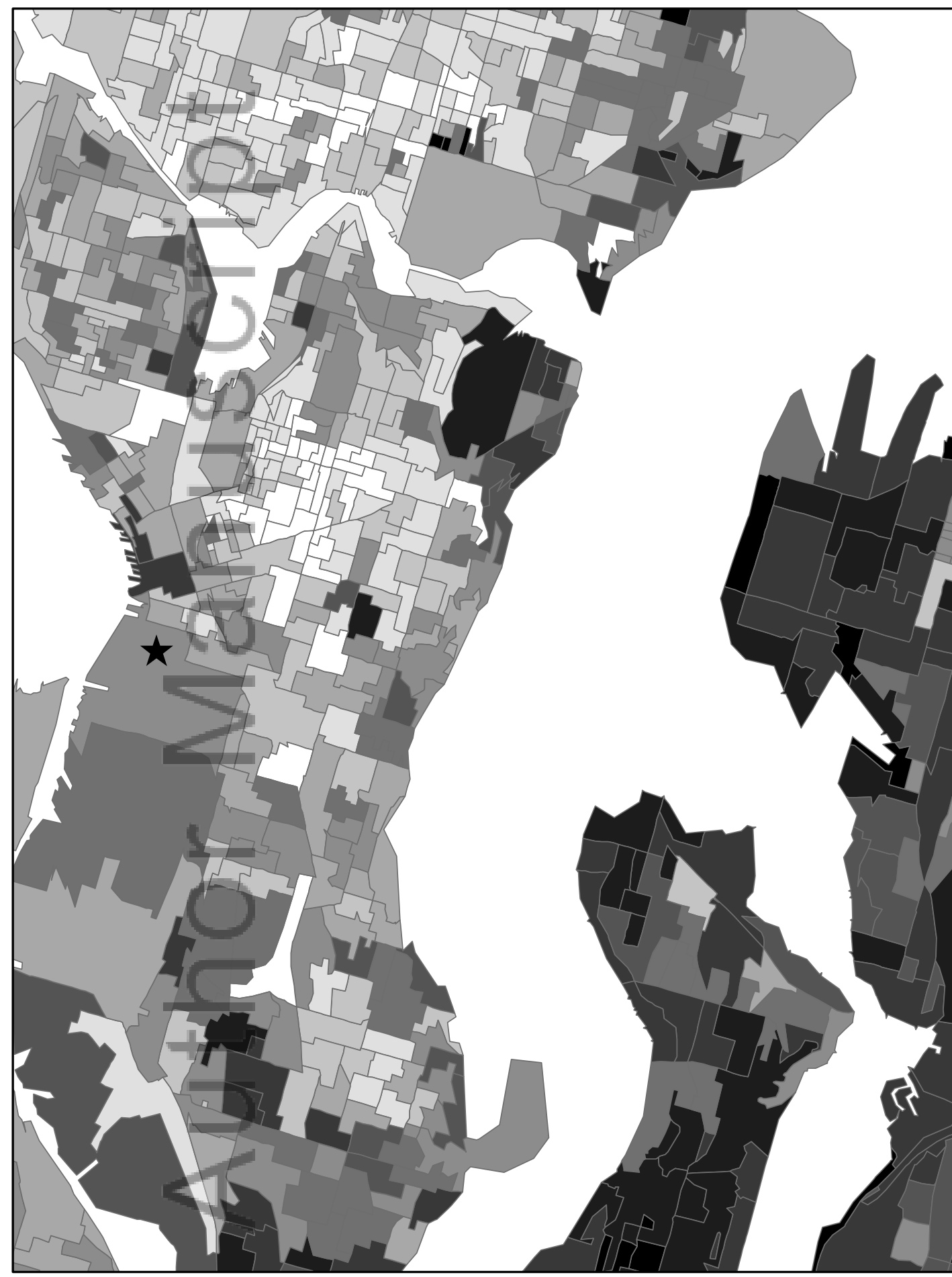

Legend

King County Qwest Field

\section{Percentage Voting Yes}

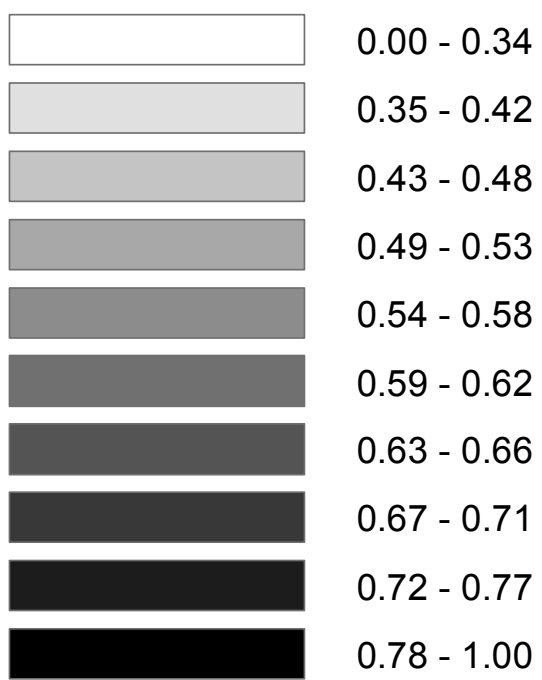

Data Sources: NHGIS (National Historical Geographic Information System) State of Washington 1997 Referendum 48 